\title{
School Entry Plays an Insignificant Role in Attention Performance, Impulse Control, and Motor Activity of Same-Aged Children from Preschool and Elementary School
}

\author{
Annika Kirschenkern ${ }^{1}$, Kathrin Hoberg², and Thomas Günther ${ }^{1,3}$
}

Child Neuropsychology Section, Department of Child and Adolescent Psychiatry, Psychotherapy and Psychosomatics, Medical Faculty, RWTH Aachen, Germany

Social Paediatric Centre, Division of Neuropaediatrics and Social Paediatrics, Department of Paediatrics, Medical Faculty, RWTH Aachen, Germany

Zuyd University, Faculty of Health, Heerlen, The Netherlands

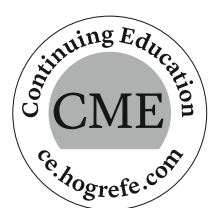

\begin{abstract}
The transition from preschool to elementary school places demands on children to pay attention, control their impulses, and avoid fidgeting. However, to the best of our knowledge, no studies have investigated whether these characteristics are influenced by elementary school entry. The current study compares same-aged preschool and elementary-school children regarding their attention performance, impulse control, and motor activity. A total of 60 children (30 preschool and 30 elementary school; 6 years old) underwent the Quantified Behavior $(\mathrm{Qb})$ Test. The children's parents responded to a conventional questionnaire for measuring attention-deficit/hyperactivity disorder. We found that formal schooling (mean: 3 months) did not significantly affect the examined variables $(p>.05)$. The results imply that improvements in questionnaire and computer test scores shown by previous studies are rather caused by maturation than the educational context. The assumption that inattention ratings increase after school entry because inattention can be better observed in an academic setting could not be verified either. Our study substantiates that the normative data used in clinical practice need not consider the educational context.
\end{abstract}

Keywords: preschool, elementary school, Quantified Behavior Test (QbTest), environmental influence, attention

Der Schuleintritt beeinflusst die Aufmerksamkeitsleistung, Impulskontrolle und motorische Aktivität von gleichaltrigen Vorschülern und Grundschülern nicht

Zusammenfassung: Der Übergang von der Vorschule zur Grundschule stellt Kinder vor die Herausforderung, ihre Aufmerksamkeit aufrecht zu erhalten, impulsives Verhalten zu kontrollieren und Unruhe zu vermeiden. Allerdings existieren nach unserem Wissen bisher keine Studien, die untersuchen, ob die genannten Verhaltensweisen durch den Grundschuleintritt beeinflusst werden. Das Ziel der aktuellen Studie ist es, die Aufmerksamkeitsleistung, Impulskontrolle und motorische Aktivität von normal entwickelten gleichaltrigen Vorschülern und Grundschülern miteinander zu vergleichen. Insgesamt führten 60 Kinder (30 Vorschüler, 30 Grundschüler; 6 Jahre alt) den Quantified Behavior (Qb) Test durch. Die Eltern der Kinder beantworteten einen konventionellen Fragebogen zur Erfassung von Symptomen einer Aufmerksamkeitsdefizit/Hyperaktivitätsstörung (ADHS). Zwischen den gleichaltrigen Vor- und Grundschülern (MW Grundschulbesuch: 3 Monate) zeigten sich keine signifikanten Unterschiede in den untersuchten Variablen ( $p>$.05). Dies impliziert, dass Verbesserungen in Fragebögen oder Computerverfahren, die vergangene Studien aufzeigten, eher auf Reifung mit dem Alter zurückzuführen sind. Die Vermutung, dass Kinder nach Schuleintritt als unaufmerksamer eingeschätzt werden, da sich Unaufmerksamkeit besser im schulischen Kontext beobachten lässt, konnte ebenfalls nicht bestätigt werden. Normdaten, die in der klinischen Praxis Verwendung finden, müssen nicht zwischen den unterschiedlichen Kontexten (Vorschule vs. Grundschule) unterscheiden.

Schlüsselwörter: Vorschule, Grundschule, Quantified Behavior Test (QbTest), Umwelteinfluss, Aufmerksamkeit 


\section{Introduction}

The transition from preschool to elementary school involves children needing to adjust to many changes, particularly regarding learning, rules, and routines (Hirst et al., 2011). While kindergarten and preschool ${ }^{1}$ are regarded as a playing environment with only minimal demands for controlling the children's attention, elementary-school students are confronted with a stricter learning environment (van Lier \& Deater-Deckard, 2016). They must acquire knowledge by sitting quietly in class, listening attentively for prolonged periods of time, following instructions, and by doing their homework. Thus, the transition to elementary school is accompanied by increasing demands placed on children to pay attention in class, to suppress any impulsive interactions with their peers as well as to inhibit their natural inclination to move and work off energy (e.g., Nelson et al., 2017).

Even though the social and educational requirements upon entering elementary school undoubtedly challenge a child's attention performance and impulsive/hyperactive behavior, little is known about how children adapt to this new environment and whether the results of different measures are directly influenced by the transition to school.

\section{The Development of Attention, Impulse Control, and Motor Activity}

The development of executive components of attention and impulse control with proceeding age has been the subject of many studies. In particular, childhood development of sustained attention has garnered extensive interest in literature, because it is needed for children to cope with environmental demands during childhood and directly influences their learning process (e.g., López et al., 2005; Sarid \& Breznitz, 1997). Most studies employed computerized tests, like the Continuous Performance Tests (CPT), to measure reaction times as well as reaction time variation, omissions, commissions, and anticipatory errors. Their general finding was that older children reacted faster, less variably, and more effectively than younger ones. In addition, attention and impulse control developed nonlinearly, increasing exponentially in early childhood and during the first school years and to a lesser extent during later childhood and adolescence (Brocki et al., 2010; Greenberg \& Waldman, 1993; Günther et al., 2014; Reichenbach et al., 1992; Rose et al., 2001; McKay et al.,
1994; Sobeh, 2010). Analogous to improvements in attention and impulse control, motor hyperactivity was also shown to improve - i.e., decrease - with age. For instance, Brocki et al. (2010) found decreasing levels of motor activity as measured in an actigraphic-based motion tracking system (MTS) of the Quantified Behavior Test (QbTest; Bergfalk, 2003).

In contrast to studies using computer tasks, CurchackLichtin et al. (2014) used parent and teacher ratings, interviews with parents, and clinician observations to investigate changes in inattention as well as impulsivity/ hyperactivity endorsement. Using a longitudinal approach (three annual measurements, starting at 4 to 5 years of age), these researchers examined both healthy children and children with attention-deficit/hyperactivity disorder (ADHD). Their study revealed that inattention scores increased over time, whereas impulsivity and hyperactivity decreased. Increasing inattention scores could be explained by school entry, suggesting that questionnaire results are not only dependent on age but also environmental influences.

\section{Environmental Influences on Attention, Impulse Control, and Motor Activity}

Environmental influences on the development of attention, impulse control, and motor activity of children have been analyzed less intensively than development with age. Duffy et al. (2009) investigated cultural influences on attentional performance with American and Japanese children and found cultural differences in the use of attention strategies adopted by 7 - to 13 -year-old children. Whereas American children used a focused strategy of attention, Japanese children exhibited a divided strategy, emphasizing contextual and nonfocal information about objects, in line with their respective cultural requirements and education. Sobeh (2010) compared German and Syrian children aged 6 to 11 years by means of computer tasks on different attention functions (the Syrian children were measured in Damascus before the war). German children showed faster reaction times, reduced reaction time variance, and lower error scores, suggesting more advanced attention and impulse inhibition than Syrian children in a sustainedattention task. Sobeh explained the good performance of German children as a result of socioculturally aided abilities to regulate selective aspects of attention. The German parents also rated their children as less inattentive, impulsive, and hyperactive in a questionnaire than Syrian par- 
ents. Interestingly, in the Syrian group, more attention parameters correlated significantly with parents' ratings than in the German group, indicating that parents from the two cultural backgrounds showed a different pattern in evaluating their children's behavior, thereby highlighting the subjectivity of questionnaires.

Apart from culture, socioeconomic influences seem to play a role in the development of attention. Ardila et al. (2005) found a positive correlation between the parent's educational level and children's performance on executive attention tasks. Consequently, a supportive and challenging environment might have enhanced the development of attention and impulse control, implying that this might also apply to the educational environment in school.

Further evidence for external factors influencing attention performance is provided by studies on attention training. A meta-analysis conducted by Peng and Miller (2016) demonstrated that attention training provided by computer tasks in form of alerting, orienting, or executive attention exercises improved performance on attention measures relative to controls. A study conducted by Halperin and colleagues (2020) revealed that a game-based intervention program for preschool children with ADHD reduced symptoms as measured by both neuropsychological computer tasks and parents' ratings.

Finally, concerning the school environment as a potential influence on the development of attention, impulsecontrol and motor-activity studies, summarized by Van Lier and Deater-Deckard (2016), suggested that there is a developmental link between school social experiences and children's executive functions including attention, working memory, and inhibitory control. They cited a study by De Wilde et al. (2015), who followed children in the early school years and found links between experiences with teachers and children's working memory development and vice versa. For instance, the level of experienced teacher-child conflicts was negatively correlated with the development of working memory. The authors concluded that working memory development can be fostered through positive social relations in school.

However, the environmental influence of preschool vs. elementary school was not or only indirectly investigated in the aforementioned studies. For instance, after recruiting children from kindergarten to grade 6, Brocki and colleagues (2010) found improvements in CPT performance and motor activity with proceeding grades. Yet, as higher grades come along with older ages, one could not differentiate between improvements because of maturation or the school environment. The same applies to the recent study conducted by Curchack-Lichtin et al. (2014), who examined children at three annual time points with a 2-year gap between preschool and elementary school (T1: ages 4-5, preschool; T2: ages 5-6; T3: ages 6-7, early school-age) by using a combination of more subjective tools (observations, interviews, and ratings, see above). As in the study of Brocki et al. (2010), impulsivity and hyperactivity decreased with age. On the one hand, because this was a longitudinal study, the improvements could be explained by the maturation of the participants. On the other hand, improvements in impulsivity and hyperactivity could be explained by training because of increasing demands on regulating attention, inhibiting responses, and controlling motor activity after entering elementary school.

In contrast to the results regarding impulsivity and hyperactivity, the endorsement rates for inattention increased over time in the study of Curchack-Lichtin et al. (2014). This applied to typically developing (TD) children as well as children with ADHD. The authors deduced that inattention can be better observed in the context of formal schooling and is less evident in nonacademic settings. Moreover, we suggest that parents' worries about the increasing demands in elementary school could cause increasing inattention scores. Previous research showed that, during the transition period into school, parents are often concerned about how their children are adjusting to starting school; they worry, for instance, about behavior difficulties, academic skills, and children's abilities to follow instructions (McIntyre et al., 2007), which may lead to an overestimation of inattention.

\section{Objective}

This current study investigates whether the transition to school influences attention performance, impulse control, and motor activity as measured by different methods. Consequently, the study was conducted on 6-year-old German children without any significant age differences who were attending either preschool or elementary school. In accordance with the study of Curchack-Lichtin et al. (2014), the parents of our 6-year-old participants were asked to answer a questionnaire used in clinical contexts to assess deficits associated with ADHD: inattention, impulsivity, and hyperactivity. As in the study of Brocki and colleagues (2010), the children underwent a CPT including movement detection capable of measuring the same variables.

Concurring with the results of Curchack-Lichtin et al. (2014), we hypothesized that the inattention questionnaire scores in elementary school would be higher -i.e., worse - than those in preschool, because questionnaires depend on the caretakers actually seeing the inattention of a particular child. Increasing worries and overrating of children's inattention because of the sudden increase in demands directly after school entry might also play a role. In contrast, we hypothesized that impulsivity and hyperac- 
tivity questionnaire scores would be lower -i.e., better - in elementary school because of environmental influences that improve both. Regarding the CPT, the results do not depend on the subjective judgment of caretakers, but on performance parameters measured for each child. Hence, we expected impulsivity and hyperactivity as well as inattention to decrease after school entry because of the challenging environment in school.

The study aims at providing fundamental knowledge on the development of attention, impulse control, and motor activity. However, it could also provide clinical implications. Children suspected of having ADHD are usually compared with age-matched peers, irrespective of the educational context. However, if a change of context like school entry affected performance of TD children already, the educational context of the children should be taken more into consideration and normative data of psychometric tests should distinguish between same-aged preschoolers and children attending school.

\section{Methods}

\section{Participants}

A total of 60 6-year-old German children, half of whom attended preschool and the other half elementary school, participated in the study (17 girls in each group; mean age of the preschoolers $=76.10$ months, $S D=1.58$ months; mean age of the elementary-school students $=76.97$ months, $S D=2.86$ months). They were all recruited by referring to the respective institutions and distributing materials inviting children's participation. Children in Germany enter school at 6 years of age in August or September. Those who turn 6 after 30 September enter school the next year. Thus, this current study examined children of the same age, who were exposed to two different environments and therefore changes in educational requirements. The elementary school children attended lessons for about 3 months (mean $=2.63$ months, $S D=1.11$ months).

The groups were matched by sex. Additionally, there were no significant age differences (in months) between the two groups $(U=383.00, p=.32)$ as well as no differences in parental socioeconomic status, measured by the parents' profession based on the International Socio-Economic Index of Occupational Status (Ganzeboom \& Treiman, 1996) (father: $U=149.50, p=.25$; mother: $U=254.50$, $p=.09$ ). Information on the parents' profession was available only for 41 children. According to interviews with the parents, the children had no previous histories of neurological or developmental disorders as well as no diagnosed
ADHD. Furthermore, the children all showed normal or corrected to normal vision and hearing.

The study was approved by the Medical Ethical Committee of the University Hospital in Aachen (EK107/18). Informed parental consent was obtained, and children orally gave their consent to participate. Participants received a present in form of toys or cinema coupons, and parents received a report on their children's performance in the computer test.

\section{Measures}

\section{Parent Assessment Form for Children with ADHD and Its Version for Preschoolers (FBB-ADHS-V)}

The FBB-ADHS ("Fremdbeurteilungsbogen für Aufmerksamkeitsdefizit-Hyperaktivitätsstörungen,” extracted from the DISYPS-II) and the FBB-ADHS-V, introduced by Döpfner et al. (2008), are parent or teacher report forms that are used to detect the three cardinal symptoms of ADHD (inattention, impulsivity, and hyperactivity). The FBB-ADHS questionnaire, geared to children of ages $4-18$, was distributed to the parents of the elementary school children in this study. It consists of 20 items rated on a 4-point answer scale ranging from $0=$ not at all to $3=$ very much. Nine items are combined into a subscale assessing inattention, whereas seven items measure hyperactivity and four items measure impulsivity. The preschool version, adapted to preschoolers/kindergarten children aged 3 to 6 years, was given to the parents of the preschoolers. The FBB-ADHS-V consists of 19 items, 9 of which cover the attention scale, 6 of which provide information on hyperactivity, and the remaining 4 items concern impulsivity. To compensate for the different numbers of items in the two questionnaires, the scores were calculated by dividing the sum of points on the 4-point answer scale by the number of items per symptom domain.

\section{The Quantified Behavior Test 6-12 (QbTest 6-12)}

The QbTest (Ulberstad, 2012) is a neuropsychological computer test suitable for children aged 6 to 12 years; it comprises a CPT measuring inattention and impulsivity and a motor activity test assessing hyperactivity.

In the case of the QbTest, the CPT is a Go/No-go task that involves the presentation of a gray circle (target) and a gray circle with a cross (nontarget), both presented at the center of the screen on a background colored in a lighter gray. The children are asked to press a button whenever the gray circle appears. Emphasis is put on both speed and accuracy. In $50 \%$ of the cases, the target and in the remaining $50 \%$ of the cases the nontarget appears. The stimuli are each presented for $100 \mathrm{~ms}$ at a rate of one stim- 
ulus every $2000 \mathrm{~ms}$. Total duration of the test is $15 \mathrm{~min}-$ utes (Ulberstad, 2012). In this study, the stimuli were presented on a "Latitude E5530 non vPro" Dell 15.6" laptop monitor with a resolution of $1366 \times 768$ pixels.

Motor activity was measured by an infrared camera attached to a tripod in front of the child. This camera does not make any recordings of the child but detects reflections of a marker attached to a headband. The participant's activity during the test was recorded by reading the coordinates (X and Y) of the headband marker (Ulberstad, 2012). The position of the marker is tracked 50 times per second, with a spatial resolution of $1 / 27 \mathrm{~mm}$ per camera unit.

Figure 1 provides a picture of the whole setting, including the devices needed for the test. Table 1 provides infor- mation on the activity measures and CPT measures used for the current study.

\section{Procedure}

Participants were tested in different locations, either at the University Hospital, the Institute of Psychology in Aachen, in schools, kindergartens, or at home. The testing sessions took place in a separate and quiet room. Depending on the requests of the children, the caretakers waited silently inside the room or were not present at all. The QbTest was administered in the morning or afternoon (not after $5 \mathrm{pm}$ ), leaving a break after lunch to avoid the postlunch dip (cf. Günther et al., 2012).

Table 1. QbTest output variables including their definitions and the constructs that they measure, as described by Ulberstad (2012)

\begin{tabular}{lll}
\hline Variable & Definition & Construct \\
\hline Reaction time (ms) & Average reaction time of all correct reactions & Inattention \\
Reaction time variation (ms) & $\begin{array}{l}\text { Inconsistency in responses, calculated by the standard deviation of the mean } \\
\text { of correct response times }\end{array}$ & Impulsivity \\
Omissions (\%) & Percentage of missed targets & Hyperactivity \\
Commissions (\%) & Percentage of false positive reactions & \\
Microevents & Tiny movements of the reflector that occur when the position changes more & than 1 mm since the last microevent \\
Distance $(\mathrm{m})$ & Total distance that the reflector moves in the testing session & \\
Area $\left(\mathrm{cm}^{2}\right)$ & Total area the reflectors cover &
\end{tabular}

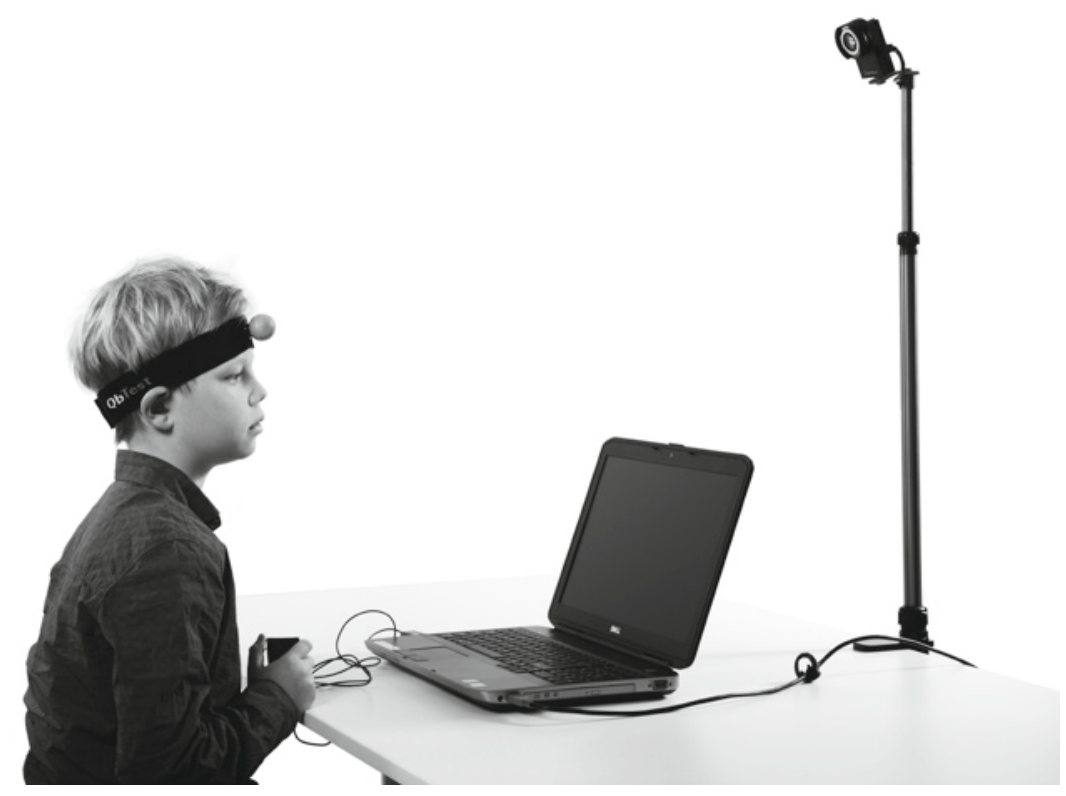

Figure 1. Picture of the arrangement of the devices belonging to the QbTest, including laptop, button, tripod with camera, and headband with reflector (Copyright @ 2020 Qbtech AB). 
Participants were instructed by showing them DIN A4 cards with the target and nontarget. Then a short exercise trial was executed. If the children gave the impression that they had understood the task, the QbTest was started.

During the testing session, participants were seated on a chair without a backrest or armrest to ensure that they did not adopt a reclining posture. The $\mathrm{Qb}$ laptop was positioned on a small table at a viewing distance of about $50 \mathrm{~cm}$. The table was adjusted to a height appropriate for the 6-yearold children. The camera was positioned at a distance of $100 \mathrm{~cm}$ from the children and adjusted in height, depending on the children's size and sitting posture.

\section{Statistical Analyses}

To address the questionnaire scores, we performed three independent samples $t$-tests, using the educational environment (preschool vs. elementary school) as the independent variable and inattention, impulsivity, and hyperactivity measures as dependent variables.

To answer how computer test results are influenced by the transition to school, we performed one statistical analysis for each ADHD symptom. Two one-way multivariate analyses of covariance (MANCOVA) were done for inattention (measured by reaction time, reaction time variation, and omissions) and hyperactivity (measured by microevents, area, and distance). A further one-way analysis of covariance (ANCOVA) was conducted to address the dependent variable impulsivity measured only with the number of commission errors. The educational environment (preschool vs. elementary school) was used as a fixed factor in the analyses. Because previous studies (e.g., Günther et al.,
2012; Kraemer et al., 2000) had demonstrated that the time of the day has an impact on attentional performance, and because morning and afternoon testing sessions were not equally distributed among preschoolers and elementary school children, we included the time of testing as a continuous covariate. Data aggregation and statistical analyses were carried out with SPSS Statistics 25 (IBM Corp., 2017). The graph was created with ggplot2 (Wickham, 2009) in R version 3.6.2 (R Core Team, 2019).

\section{Results}

Figure 2 graphically presents the inattention-, impulsivity, and hyperactivity scores for preschoolers vs. elementaryschool children. To create comparability between the scores, we calculated $t$-values. In addition, because inattention and hyperactivity were measured by different variables in the QbTest, we decided to plot a composite score for inattention and hyperactivity for the sake of clarity within the summarizing figure. More specifically, we used the mean $t$-values of reaction time, reaction time variation, and omissions to create the composite inattention score. The respective mean $t$-values of microevents, area, and distance were used to create the composite hyperactivity score.

To confirm the lack of differences between preschoolers and elementary-school students regarding most measures and to further address the effect in the QbTest hyperactivity score, we provide the statistical information as well as the means of every single variable in the subsequent sections.

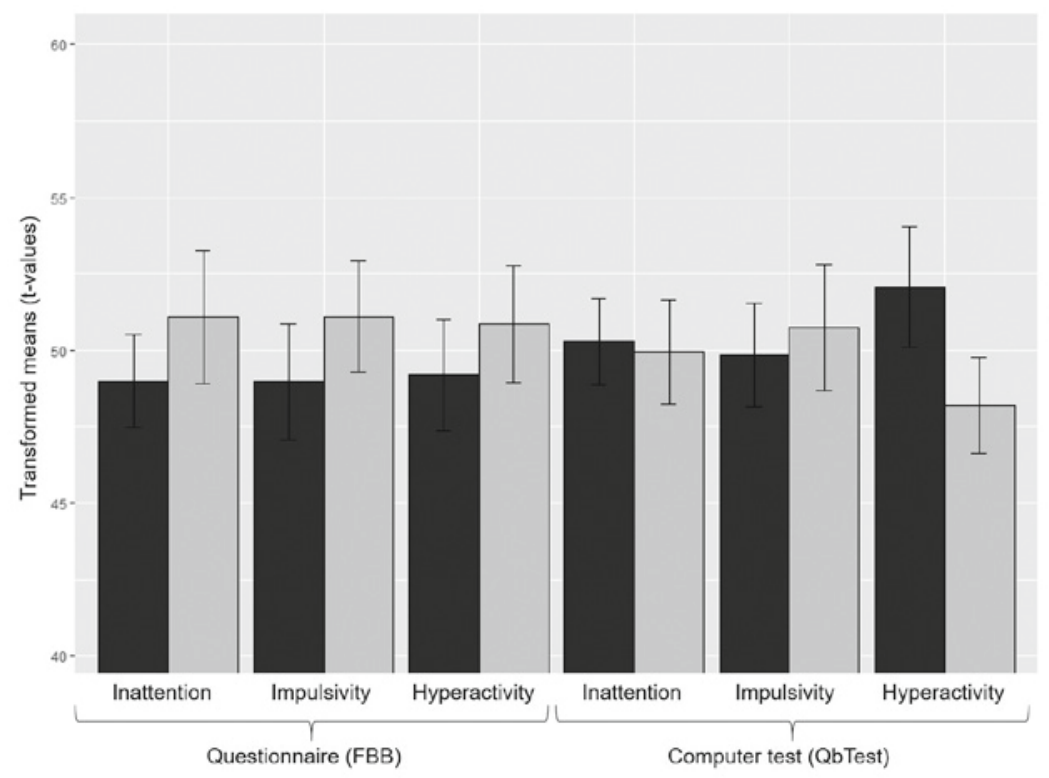

Educational environment

Elementary school

Preschool

Figure 2. Transformed t-values for inattention-, impulsivity- and hyperactivity scores in preschoolers compared to elementary school children, including standard error bars. As with the raw data, low t-values indicate low levels of inattention, impulsivity or hyperactivity. 


\section{Questionnaire Results}

Contrary to our expectations, school entry did not have a significant effect on questionnaire results $(p>.05)$. Thus, there were no significant differences in parents' judgments of inattention, impulsivity, and hyperactivity of children who attended preschool compared with children who were exposed to greater demands on attention in school. Table 2 provides descriptive statistics as well as the $t$-test results.

\section{Computer Test Results}

The MANCOVA with reaction time, reaction time variation, and omissions (inattention measures) as dependent variables did not show a significant effect of educational environment, Pillai's trace $=.062, F(3,55)=1.214, p=.313$, $\eta p 2=.062$, confirming the lack of difference between preschoolers and elementary-school students regarding attentional performance. The time of testing did not influence attention measures, Pillai's trace $=.003, F(3,55)=$ $.059, p=.981, \eta p 2=.003$.
The between-subjects result of the ANCOVA with commissions (impulsivity measure) as the dependent variable revealed a similar result: Preschoolers and elementaryschool students did not differ in their number of false positive mistakes, $F(1)=.069, p=.793, \eta p 2=.001$, and the time of testing did not play a significant role, $F(1)=.121, p=$ $.730, \eta p 2=.002$.

The MANCOVA with microevents, distance, and area (hyperactivity measures) as dependent variables did not show a significant effect of educational environment either, Pillai's trace $=.090, F(3,55)=1.814, p=.155, \eta p 2=$ .090 , indicating that school entry did not influence motor activity. Time of testing as a covariate had a marginally significant, effect Pillai's trace $=.123, F(3,55)=2.561, p=$ $.064, \eta p 2=.123$, and the size of this effect was small. Yet, it presumably explains the small difference in the QbTest hyperactivity measures between preschoolers and elementary-school students, indicated by a visual inspection of Figure 2, in the sense that elementary-school students were tested more often in the afternoon and therefore showed a small tendency toward a higher motor activity. Table 3 shows descriptive statistics as well as all between-subjects effects.

Table 2. Differences in the questionnaire results (inattention, impulsivity, and hyperactivity) between the different groups (preschoolers and elementary-school children)

\begin{tabular}{|c|c|c|c|c|c|}
\hline \multirow[t]{2}{*}{ Questionnaire results } & Preschool $(N=28)$ & Elementary school $(N=30)$ & $t(d f=56)$ & $\mathrm{p}$ & Cohen's $d$ \\
\hline & Mean (SD) & \multicolumn{4}{|l|}{ Mean (SD) } \\
\hline Inattention quotient & $.564(.624)$ & $.450(.448)$ & -.798 & .428 & 0.210 \\
\hline Impulsivity quotient & $.759(.579)$ & $.632(.619)$ & -.807 & .423 & 0.212 \\
\hline Hyperactivity quotient & $.506(.587)$ & $.409(.584)$ & -.634 & .528 & 0.166 \\
\hline
\end{tabular}

Note. Scores of the FBB questionnaires were calculated by dividing the points on the 4-point answer scale by the number of items per cardinal symptom. Two questionnaires of preschoolers were not returned.

Table 3. Differences in the QbTest results (inattention, impulsivity, and hyperactivity) between the different groups (preschoolers and elementaryschool children): Tests of between-subjects effects

\begin{tabular}{|c|c|c|c|c|c|c|}
\hline \multirow{2}{*}{$\begin{array}{l}\text { QbTest results } \\
\text { Mean (SD) }\end{array}$} & & Preschool $(N=30)$ & Elementary school $(N=30)$ & $F(d f=1)$ & $\mathrm{p}$ & пр2 \\
\hline & & \multicolumn{5}{|l|}{ Mean (SD) } \\
\hline \multirow[t]{3}{*}{ Inattention } & Reaction time (ms) & $652.333(154.525)$ & $695.233(116.438)$ & 1.232 & .272 & .021 \\
\hline & Reaction time variation (ms) & $200.43(55.263)$ & $209.63(59.577)$ & .233 & .631 & .004 \\
\hline & Omissions (\%) & $14.213(12.662)$ & $10.873(8.691)$ & .956 & .332 & .016 \\
\hline Impulsivity & Commissions (\%) & $10.060(9.226)$ & $9.790(7.974)$ & .069 & .793 & .001 \\
\hline \multirow[t]{3}{*}{ Hyperactivity } & Microevents & $13123.97(5667.790)$ & $15923.33(6336.903)$ & 2.911 & .093 & .049 \\
\hline & Distance (m) & $23.347(12.524)$ & $29.760(19.191)$ & 1.111 & .296 & .019 \\
\hline & Area $\left(\mathrm{cm}^{2}\right)$ & $93.733(51.035)$ & $117.100(64.256)$ & 1.334 & .253 & .023 \\
\hline
\end{tabular}

Note. Reaction time outliers were automatically discarded and are not included in the reaction time data. 


\section{Discussion}

\section{The Influence of School Entry on Questionnaire Data Filled in by the Parents}

Our first set of hypotheses concerned the questionnaire scores. We predicted that the inattention questionnaire score in elementary school would be higher - i.e., worse than in preschool, because inattention is not visible to parents before demands are put on attention in elementary school. Parents' worries about increasing demands in the academic context of elementary school, compared to the playing environment in preschool, could also play a role. Furthermore, we hypothesized that impulsivity and hyperactivity scores would be lower in elementary school than in preschool because of training induced by the challenging school environment. Both assumptions could not be confirmed as preschoolers and elementary-school students did not differ in their questionnaire results.

With reference to attention, results may indicate that parents can evaluate their children's attention skills in preschool as well as in elementary school. The FBB-ADHS-V, a questionnaire adapted for preschoolers, may have helped parents evaluate attention in the playing environment in preschool. In addition, results suggest that parents' general concerns during their children's transition period into school (McIntyre et al., 2007) are not reflected in inattention ratings a few months after school entry. Possibly parents were not worried regarding their children's attention skills because their children adapted well to the new challenges in school. ${ }^{2}$ On the other hand, inattention scores may have remained at the same level after school entry because parents could not directly observe children in their learning environment (in contrast to teachers) and hence could still not detect inattention.

Our results disagree (at first glance) with the results of Curchack-Lichtin et al. (2014), who tested both healthy children and ADHD children and found increasing inattention scores after school entry. This is probably because of methodological differences. First, Curchack-Lichtin and colleagues used two questionnaires, completed by both teachers and parents, a semistructured interview with the parents as well as clinician observations. Symptom endorsements were then based upon a combination of these assessments. Unfortunately, sample characteristics for each measure and for inattention and impulsivity/ hyperactivity were not reported separately. Therefore, it is not possible to confirm how the changes over time in inattention scores occurred and to retrace, for instance, which role interviews with the parents played. Only the results of one questionnaire were reported separately for inattention and impulsivity/hyperactivity, showing an increase in teachers' inattention ratings, whereas parents' ratings remained at a broadly similar level over the three annual time points. This supports the assumption that inattention after school entry could be better detected by the teachers.

Moreover, and in contrast with the study of CurchackLichtin et al. (2014), children in the current study had attended school for a short amount of time. Presumably, the demands in the first months of school were not that great or teachers were more tolerant during the first half of the year. These teachers may not have given realistic feedback about the students' attention capacity during classes and hence parents would not have had any reason to be worried until later in the school year.

Our finding that impulsivity and hyperactivity ratings did not decrease after school entry disagrees with the study of Curchack-Lichtin and colleagues (2014) as well. It seems likely that improvements in questionnaires scores in the aforementioned study were caused by maturation and/or a longer time in school. Regarding previous studies on questionnaire improvements because of attention training, it is reasonable that training cannot be directly compared with the school environment. The challenging school environment is different from a targeted play-based attention training or computer training, since the school setting is more complex and provides little control over influential factors. In addition, studies on attention training mostly focused on a clinical population. For example, Halperin et al. (2020) found improvements in parents' ratings after executing a play-based intervention program with children affected with an ADHD diagnosis. However, we tested TD children whose attention skills are generally normal and hence may not increase markedly.

\section{The Influence of School Entry on Computer Test Data}

Our second set of hypotheses concerned the QbTest scores. Neuropsychological computer tests are not dependent on caretakers' observations and can detect even the slightest changes in terms of reaction times in milliseconds or the smallest of movements. Thus, we hypothesized that attention, impulse control, and motor activity as measured by a precise instrument would show improvements because of the challenging and supportive school

\footnotetext{
Note that concerns were not directly measured in our study, but increasing ratings of inattention could have been an indirect indicator of parents' worries on children's attention skills, for example, by overinterpretation of inattentive symptoms.
} 
environment. This hypothesis could not be confirmed: Preschoolers and elementary-school students showed similar skills regarding attention, impulse control, and motor activity.

These results suggest that improvements in computer test results after school entry in the study by Brocki et al. (2010), which provided developmental data by means of a cross-sectional sample, were caused by age and maturation and not the educational requirements in school. In addition, and in contrast with previous studies that found improvements in computer test results depending on the parents' educational level or culture (e.g., Ardila et al., 2005; Sobeh, 2010), our study suggests that the presence in school for a couple of months (maximum 5 months in the current study) does not have such a wide-ranging influence. The reason for this may be that both parents' educational level, leading to a supportive and challenging environment throughout childhood, and the cultural background are longer and more formative factors than a short presence in the academic environment of school. One also needs to call into question whether the parents' educational level influences attentional processes by providing a supportive environment or whether the children of more highly educated parents simply inherit a higher IQ or a propensity toward having good attention skills (the IQ was not assessed in the study of Ardila et al., 2005).

Note that it is still possible that the school environment positively influences attention skills, impulse control, or motor activity, though a training effect may manifest only after a longer exposure to the school environment. Or maybe school starts off slowly, and demands are not that great so that school entry does not induce a training effect in the beginning.

\section{Limitations}

The current study was subject to several limitations, some of which were addressed above: Elementary-school students had attended school for only 3 months. It would have been interesting to examine children who had attended school longer. This is, however, difficult to investigate excluding the effects of a child's maturation over time. In addition, we asked parents to fill in a questionnaire but did not combine several sources of (subjective) information, such as teachers' ratings or a structured interview for ADHD symptoms.

Moreover, the children were not tested in the same environment. Preschoolers were tested more often in kindergarten than elementary-school students were tested in their respective schools. On the one hand, it is thus possible that preschoolers felt more comfortable in their famil- iar surroundings and were less distracted than the elementary-school students who were tested more often in a presumably more interesting test chamber. On the other hand, preschoolers may have been more distracted by their room in kindergarten, knowing about the books or toys in the shelves, which would have influenced group differences as well.

A further limitation pertains to the characteristics of the schools. For example, we did not assess how challenging or supportive the schools were or how many hours children spent at school. This information would have enabled a better understanding of the demands put on the children. We also did not ask whether the children did their homework at home or whether they joined an afternoon program in school and did their homework there. In fact, none of the questions in the FBB-ADHS refers solely to homework, but rating children's attentional performance should be easier if parents could evaluate the homework situation and observe how their children deal with academic tasks requiring sustained mental effort.

Furthermore, the sample size $(N=60)$ can be considered a limitation. The small sample size alone cannot explain why we could not replicate the results of CurchackLichtin et al. (2014), who included data from 88 (T3) healthy participants. As calculated with $G^{*}$ Power (Faul et al., 2009), even with our smaller sample we should have been able to find the moderate effect of $\eta \mathrm{p} 2=.35$ reported by the researchers. Yet, small improvements induced by the school environment (instead of possibly greater effects because of maturation) were perhaps not detected in our small sample size.

Lastly, we would like to point out that we only ruled out ADHD based on information received from the participants' parents and then included all the children (also children with test results beyond the norm, reflecting the variance in the normal population). However, this should not have influenced results, even as undiagnosed ADHD, fairly distributed over both groups, should have enhanced group differences (see Curchack-Lichtin et al., 2014).

\section{Conclusion and Outlook}

This study compared the results of the questionnaire FBBADHS(-V) and the computer test QbTest in preschoolers and elementary-school students. Unexpectedly, the two groups did not differ in any of the measures, indicating that parents' ratings of their children's attention skills are not influenced by the transition into school. Our present study also suggests that attention performance, impulse control, and motor activity are not improved by a few months of school attendance, but rather improve with age, 
caused by maturation or presumably by long-term school effects.

Even though this study reports no differences between preschool and elementary-school students, it still provides valuable clinical implications: In clinical practice, the norm data of questionnaires and computer tests do not need to distinguish between same-aged preschoolers and children attending school. Yet, clinicians should take care to use a questionnaire appropriate to the preschool context.

The current findings remain preliminary as they were subject to different kinds of limitations that should be addressed by future research. Future research could also extend the current methodological approach, for instance, by addressing important aspects of parents' attitudes during their children's transition to elementary school. Parents could be asked how much importance they placed on academic achievement, and how worried they were about their children doing well in school. In addition, future research could apply a repeated measures approach in the sense that the same children are tested both right at the end of preschool and then again in elementary school. Possible improvements should then be compared against improvements in a similar timespan to exclude for simple maturational processes. It would also be interesting to address the question of whether children with ADHD profit from the school environment or whether the effects of increasing requirements in school can be deduced using questionnaires of a clinical population.

\section{References}

Ardila, A., Rosselli, M., Matute, E., \& Guajardo, S. (2005). The influence of parents' education level on the development of executive functions. Developmental Neuropsychology, 28(1), 539-560. https://doi.org/10.1207/s15326942dn2801_5

Bergfalk, H. (2003). QbTest user manual. QbTech AB.

Brocki, K. C., Tillman, C.M., \& Bohlin, G. (2010). CPT performance, motor activity, and continuous relations to ADHD symptom domains: A developmental study. European Journal of Developmental Psychology, 7(2), 178-197. https://doi.org/10.1080/174 05620801937764

Curchack-Lichtin, J.T., Chacko, A., \& Halperin, J. M. (2014). Changes in ADHD symptom endorsement: Preschool to school age. Journal of Abnormal Child Psychology, 42(6), 993-1004. https://doi. org/10.1007/s10802-013-9834-9

De Wilde, A., Koot, H.M., \& Van Lier, P.A. (2015). Developmental links between children's working memory and their social relations with teachers and peers in the early school years. Journal of Abnormal Child Psychology, 44(1), 19-30. https://doi. org/10.1007/s10802-015-0053-4

Döpfner, M., Görtz-Dorten, A., \& Lehmkuhl, G. (2008). DiagnostikSystem für psychische Störungen nach ICD-10 und DSM-IV für Kinder- und Jugendliche (DISYPS-II). Huber.

Duffy, S., Toriyama, R., Itakura, S., \& Kitayama, S. (2009). Development of cultural strategies of attention in North American and
Japanese children. Journal of Experimental Child Psychology, 102(3), 351-359. https://doi.org/10.1016/j.jecp.2008.06.006

Faul, F., Erdfelder, E., Buchner, A., \& Lang, A.-G. (2009). Statistical power analyses using $G *$ Power 3.1: Tests for correlation and regression analyses. Behavior Research Methods, 41(4), 1149 1160. https://doi.org/10.3758/BRM.41.4.1149

Ganzeboom, H.B.G., \& Treiman, D.J. (1996). Internationally comparable measures of occupational status for the 1988 International Standard Classification of Occupations. Social Science Research, 25(3), 201-239. https://doi.org/10.1006/ssre.1996.0010

Greenberg, L.M., \& Waldman, I.D. (1993). Developmental normative data on the Test of Variables of Attention (T.O.V.A.). Child Psychology \& Psychiatry \& Allied Disciplines, 34(6), 1019-1030. https://doi.org/10.1111/j.1469-7610.1993.tb01105.x

Günther, T., Kahraman-Lanzerath, B., Knospe, E. L., Herpertz-Dahlmann, B., \& Konrad, K. (2012). Modulation of attention-deficit/ hyperactivity disorder symptoms by short- and long-acting methylphenidate over the course of a day. Journal of Child and Adolescent Psychopharmacology, 22(2), 131-138. https://doi. org/10.1089/cap.2010.0146

Günther, T., Konrad, K., Häusler, J., Saghraoui, H., Willmes, K., \& Sturm, W. (2014). Developmental differences in visual and auditory attention: A cross-sectional study. Zeitschrift für Neuropsychologie, 25(3), 143-152. https://doi.org/10.1024/1016-264X/ a000126

Halperin, J.M., Marks, D.J., Chacko, A., Bedard, A.C., O’Neill, S., Curchack-Lichtin, J., Bourchtein, E., \& Berwid, O.G. (2020). Training executive, attention, and motor skills (TEAMS): A preliminary randomized clinical trial of preschool youth with ADHD. Journal of Abnormal Child Psychology, 48(3), 375-389. https:// doi.org/10.1007/s10802-019-00610-w

Hirst, M., Jervis, N., Visagie, K., Sojo, V., \& Cavanagh, S. (2011). Transition to primary school: A review of the literature. Commonwealth of Australia.

IBM Corp. (2017). IBM SPSS Statistics for Windows, Version 25.0. Author.

Kraemer, S., Danker-Hopfe, H., Dorn, H., Schmidt, A., Ehlert, I., \& Herrmann, W. M. (2000). Time-of-day variations of indicators of attention: Performance, physiologic parameters, and self-assessment of sleepiness. Biological Psychiatry, 48(11), 10691080. https://doi.org/10.1016/S0006-3223(00)00908-2

López, F., Menez, M., \& Hernández-Guzmán, L. (2005). Sustained attention during learning activities: An observational study with pre-school children. Early Child Development and Care, 175(2), 131-138. https://doi.org/10.1080/0300443042000230384

McIntyre, L., Eckert, T., Fiese, B., DiGennaro, F.D., \& Wildenger, L. (2007). Transition to kindergarten: Family experiences and involvement. Early Childhood Education Journal, 35, 83-88. https://doi.org/10.1007/s10643-007-0175-6

McKay, K.E., Halperin, J.M., Schwartz, S.T., \& Sharma, V. (1994). Developmental analysis of three aspects of information processing: Sustained attention, selective attention, and response organization. Developmental Neuropsychology, 10(2), 121-132. https://doi.org/10.1080/87565649409540572

Nelson, T.D., Nelson, J.M., James, T.D., Clark, C.C., Kidwell, K.M., \& Espy, K.A. (2017). Executive control goes to school: Implications of preschool executive performance for observed elementary classroom learning engagement. Developmental Psychology, 53(5), 836-844. https://doi.org/10.1037/dev0000296

Peng, P., \& Miller, A.C. (2016). Does attention training work? A selective meta-analysis to explore the effects of attention training and moderators. Learning and Individual Differences, 45, 77-87. https://doi.org/10.1016/j.lindif.2015.11.012

R Core Team (2019). R: A language and environment for statistical computing. R Foundation for Statistical Computing. Retrieved from https://www.R-project.org/ 
Reichenbach, L.C., Halperin, J.M., Sharma, V., \& Newcorn, J.H. (1992). Children's motor activity: Reliability and relationship to attention and behavior. Developmental Neuropsychology, 8(1), 87-97. https://doi.org/10.1080/87565649209540517

Rose, C.L., Murphy, L.B., Schickedantz, B., \& Tucci, J. (2001). The effects of event rate and signal probability on children's vigilance. Journal of Clinical and Experimental Neuropsychology, 23(2), 215-224. https://doi.org/10.1076/jcen.23.2.215.1205

Sarid, M., \& Breznitz, Z. (1997). Developmental aspects of sustained attention among 2- to 6-year-old children. International Journal of Behavioral Development, 21(2), 303-312. https://doi. org/10.1080/016502597384884

Sobeh, J. (2010). Aufmerksamkeitsfunktionen und ihre Entwicklung bei Vorschul- und Grundschulkindern: eine kulturvergleichende Studie zur Erfassung von neuropsychologischen Funktionen der Aufmerksamkeit bei einer Stichprobe von Kindern in Damaskus (Syrien) und Aachen (Deutschland). Cuvillier.

Ulberstad, F. (2012). QbTest Technisches Manual. Qbtech AB.

Van Lier, P.A.C., \& Deater-Deckard, K. (2016). Children's elementary school social experience and executive functions development: Introduction to a special section. Journal of Abnormal Child Psychology, 44(1), 1-6. https://doi.org/10.1007/s10802-015-0113-9

Wickham, H. (2009). ggplot2: Elegant graphics for data analysis. Springer.

\section{History}

Manuscript submitted: 26.02.2021

Accepted after revision: 25.10.2021

Published online: 07.12.2021

\section{Acknowledgments}

The QbTest system used for the current study was provided by QbTech AB.

\section{Conflicts of Interests}

There are no conflicts of interest.

\section{Annika Kirschenkern}

Child Neuropsychology Section

Department of Child and Adolescent Psychiatry, Psychotherapy, and Psychosomatics

University Hospital Aachen

Pauwelsstraße 30

52074 Aachen

Germany

akirschenkern@ukaachen.de

\section{CME-Fragen}

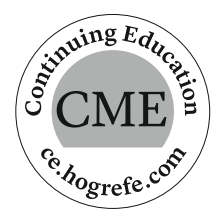

\section{Frage: Welche Aussagen zum CPT treffen zu? (Mehrfachwahl)}

a. CPT steht für „Continuous Performance Test“.

b. Der CPT ist ein neuropsychologisches Testverfahren zur Erfassung von visuell-räumlichen Aspekten der Aufmerksamkeit und wird z.B. zur Diagnostik bei Neglect eingesetzt.

c. Der CPT ist ein Fremdbeurteilungsbogen zur Erfassung der Symptomkriterien einer ADHS.

d. Der CPT ist ein Selbstbeurteilungsbogen zur Erfassung der Symptomkriterien einer ADHS.

e. Der CPT ist ein neuropsychologisches Testverfahren zur Erfassung von selektiver Aufmerksamkeit und Daueraufmerksamkeit.

\section{Frage: Welche Aussage zur Entwicklung von Aufmerksamkeit und Impulskontrolle treffen zu? (Mehrfachwahl)}

a. Die Entwicklung erfolgt bis ins hohe Alter linear.

b. Die Entwicklung erfolgt nicht-linear.

c. In der frühen Kindheit und in den ersten Schuljahren erfolgt eine exponentielle Entwicklung, während sich in der späteren Kindheit und Jugend weniger starke Verbesserungen zeigen.

d. Die stärkste Entwicklung erfolgt mit Reifung des präfrontalen Cortex im Jugendalter bzw. frühen Erwachsenenalter. e. Mit Übergang in die weiterführende Schule und damit der Konfrontation mit erhöhten Anforderungen ans Lernen erfolgt die stärkste Entwicklung.

\section{Frage: Was zählt zu den drei klassischen Kern- symptomen einer ADHS? (Einfachwahl)}

a. Aufmerksamkeitsdefizit, Anhedonie, vermindertes Selbstwertgefühl

b. Impulsivität, Aufmerksamkeitsdefizit, niedrige Frustrationstoleranz

c. Impulsivität, Hyperaktivität, niedrige

Frustrationstoleranz

d. Impulsivität, Hyperaktivität, Aufmerksamkeitsdefizit

e. Aufmerksamkeitsdefizit, Hyperaktivität, hohe Empfindsamkeit

\section{Frage: Frage: Welche Aussage zum QbTest trifft zu? (Mehrfachwahl)}

a. Der QbTest ist ein CPT.

b. Der QbTest erfasst die drei Kardinalsymptome einer ADHS.

c. Beim QbTest wird mithilfe eines Stirnbands mit Reflektor die Impulskontrolle einer Patientin/eines Patienten oder einer Probandin/eines Probanden erfasst.

d. Beim QbTest werden Gehirnstromkurven (EEG-

Wellen) von einem Computer in Echtzeit analysiert.

e. Der QbTest ist ein invasives Testverfahren. 


\section{Frage: Welche Aussage ist nicht zutreffend? (Mehrfachwahl)}

a. Computerisierte neuropsychologische Testverfahren ermöglichen im Gegensatz zu Fragebogenverfahren eine objektive Messung der Aufmerksamkeitsfunktionen.

b. Gleichaltrige Vorschulkinder und Grundschulkinder unterscheiden sich deutlich bzgl. Ihrer Reaktionszeiten in einer computerisierten

Daueraufmerksamkeitsaufgabe. c. Während der Übergangsphase in die Grundschule machen sich viele Eltern Sorgen bzgl. Verhaltensschwierigkeiten oder der akademischen Fähigkeiten ihrer Kinder (z. B. McIntyre et al., 2007).

d. Man geht davon aus, dass Aufmerksamkeitsprobleme in nicht-akademischen Settings weniger auffallen.

e. Fragebogenverfahren, die verschiedenen Bezugspersonen eines Kindes (z. B. Lehrpersonen und Eltern) zur Einschätzung gegeben werden, ermöglichen eine objektive Bewertung von Symptomkriterien einer ADHS.
Um Ihr CME-Zertifikat zu erhalten (min. drei richtige Antworten), schicken Sie bitte den ausgefüllten Fragebogen mit einem frankierten Rückumschlag bis zum 30.04.2023 an die nebenstehende Adresse. Später eintreffende Antworten und solche ohne bzw. mit nicht frankierten Rückumschlägen können nicht mehr berücksichtigt werden.

\section{Luisa Schula}

LWL-Universitätsklinik Hamm der Ruhr-Universität Bochum Klinik für Kinder- und Jugendpsychiatrie, Psychotherapie und Psychosomatik

Heithofer Allee 64

59071 Hamm, Deutschland

\section{Fortbildungszertifikat}

\section{Die Ärztekammer Niedersachsen erkennt hiermit zwei Fortbildungspunkte an.}

\section{Stempel \\ Kinder- und Jugend- \\ psychiatrie und \\ Psychotherapie \\ $02 / 2023$ \\ (w) hogrefe}

Wichtig: Bitte kleben Sie hier Ihr Barcode-

Etikett (EFN) an oder schreiben Sie Ihre EFN.

Bitte teilen Sie uns alternativ Ihre

Psychotherapeuten-Fortbildungsnummer mit:
„Attention, Impulse Control, and Motor Activity in Different Contexts“

Die Antworten bitte deutlich ankreuzen!

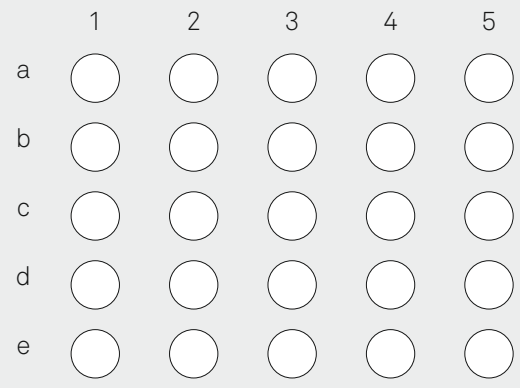

Ich versichere, alle Fragen ohne fremde Hilfe beantwortet zu haben.

Name

Berufsbezeichnung, Titel

Straße, Nr.

PLZ, Ort 